\title{
Analisis Pengaruh Faktor Internal dan Faktor Eksternal Terhadap Non-Performing Financing pada Bank Umum Syariah
}

\author{
Analysis of the influence of internal and external factors on non-performing financing in \\ Islamic commercial banks
}

\section{Framesa Januari Rahmah}

Program Studi D4 Keuangan Syariah Politeknik Negeri Bandung

Email: framesa.januari.ksy16@polban.ac.id

\section{Leni Nur Pratiwi}

Jurusan Akuntansi, Politeknik Negeri Bandung

Email: leni.pratiwi@polban.ac.id

\section{Iwan Setiawan}

Jurusan Akuntansi Politeknik Negeri Bandung

Email: iwan.setiawan@polban.ac.id

\begin{abstract}
Islamic banking at the moment is one of the most important things in the economy in Indonesia. Non Performing Financing (NPF) is one of the ratio that is considered by Islamic banking. NPF is an indicator that shows the risk ofpayment failure in the financing provided by Islamic banking. This study aims to analyze the influence of internal factors and external factors on Non-Performing Financing. The study was conducted at Islamic Commercial Banks in Indonesia for the 2014-2018 period. The internal variables used are the Capital Adequacy Ratio (CAR) and the Financing to Deposit Ratio (FDR) and the external variables used are the inflation rate, Gross Domestic Product (GDP) and the BI Rate. The results of the research shown by the t test show that partially the CAR and BI Rate variables have a negative effect on NPF meanwhile FDR, inflation and GDP variables have no effect on NPF.
\end{abstract}

Keywords: NPF, CAR, FDR, Inflation, GDP and BI Rate.

\section{Pendahuluan}

Bank Syariah pada awalnya dikembangkan sebagai hasil dari sebuah keinginan kelompok ekonom dan praktisi perbankan muslim yang berupaya menyediakan jasa transaksi keuangan yang dijalankan berdasarkan prinsip Syariah. Tidak dapat dipungkiri bahwa perkembangan Perbankan Syariah di Indonesia dapat dikatakan cukup pesat. Pesatnya perkembangan Perbankan Syariah ini dapat dilihat dari jumlah Bank Umum Syariah di Indonesia yang terus meningkat dari tahun ke tahun, jumlah bank meningkat dari hanya 9 Bank Umum Syariah pada tahun 2009 hingga pada tahun 2018 tercatat ada 13 Bank Umum Syariah yang beroperasi di Indonesia. Dengan diberlakukannya Undang-Undang No. 21 Tahun 2008 tentang Perbankan Syariah yang diterbitkan pada tanggal 16 Juli 2009, maka pengembangan industri Perbankan Syariah nasional semakin kuat karena telah memiliki landasan hukum yang memadai dan akan mendorong pertumbuhannya secara lebih cepat lagi. Penambahan jumlah bank tentunya akan disertai dengan meningkatnya jumlah dana investasi yang tersedia, sehingga diharapkan kemampuan bank dalam 


\section{Framesa Januari Rahmah, Leni Nur Pratiwi, Iwan Setiawan}

memberikan pembiayaan kepada masyarakat semakin meningkat.

Dilansir dari portal berita online www.kontan.co.id, Jasa Otoritas Keuangan (OJK) menegaskan bahwa likuiditas pada akhir tahun 2018 masih dalam keadaan yang longgar. Hal ini ditunjukkan dengan rasio pembiayaan dibanding Dana Pihak Ketiga (DPK) atau disebut Financing to Deposit Ratio (FDR) per agustus 2018 sebesar 89,6\% yang dapat dilihat dari Statistik Perbankan Syariah bulan Agustus 2018. Dengan artian bahwa Perbankan Syariah masih memiliki dana yang cukup besar untuk disalurkan dalam bentuk pembiayaan kepada masyarakat kedepannya. Peningkatan FDR yang terjadi sejak bulan Mei 2018 disebabkan karena adanya peningkatan jumlah penyaluran pembiayaan yang diberikan oleh bank Syariah. Namun, menurut (Hidayah, 2019) peningkatan jumlah penyaluran pembiayaan ini dapat memicu pembiayaan bermasalah atau Non Performing Financing (NPF). Dengan meningkatnya jumlah pembiayaan yang diberikan oleh bank, maka NPF juga akan meningkat. Peningkatan NPF merupakan indikasi bahwa bank dalam kondisi yang tidak baik karena semakin tinggi Non Performing Financing atau NPF, semakin tinggi risiko kredit yang akan dihadapi oleh bank Syariah. Menurut (Frianto, 2012) Risiko kredit adalah risiko kerugian yang dialami oleh bank karena nasabah debitur tidak dapat dan atau tidak mau memenuhi kewajiban untuk membayar kembali dana yang dipinjamkannya secara penuh saat jatuh tempo atau sesudahnya. Risiko yang tinggi ini akan mempengaruhi permodalan bank Syariah itu sendiri.

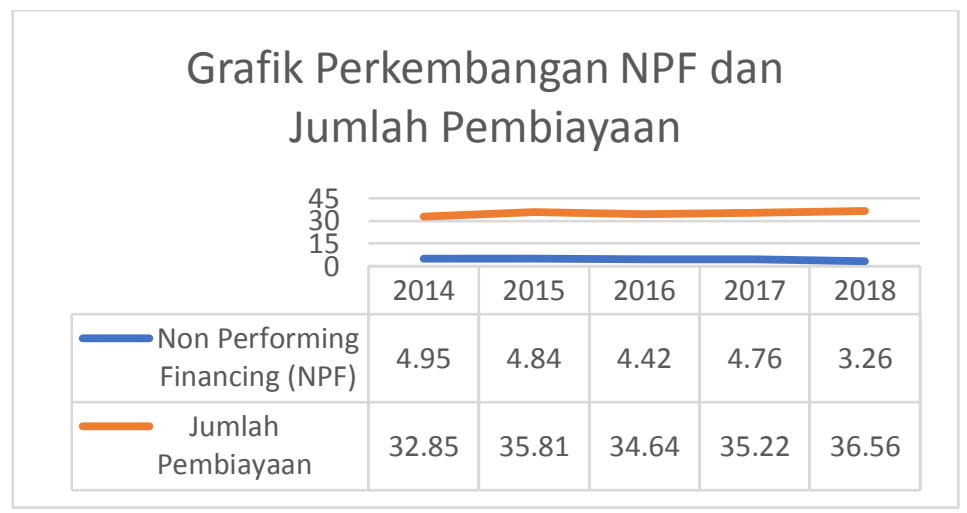

Gambar 1. Grafik Perbandingan Perkembangan NPF dan Jumlah Pembiayaan pada BUS Periode 2014-2018 dalam persen (\%)

Berdasarkan Gambar 1. di atas dapat dilihat adanya perkembangan jumlah pembiayaan dan jumlah NPF selama 5 tahun yang berfluktuatif. Namun, selama tahun penelitian tersebut ternyata terjadi kesenjangan antara jumlah pembiayaan dan jumlah NPF yang dapat dilihat pada tahun 2015 dimana jumlah pembiayaan naik menjadi 35,81\% akan tetapi terjadi penurunan NPF yang turun menjadi 4,84\%, kemudian pada tahun 2018 jumlah pembiayaan naik menjadi 36,56\% sedangkan NPF turun menjadi 3,26\%. Hal ini menunjukan bahwa kenaikan pembiayaan tidak selamanya diikuti dengan kenaikan NPF.

Pembiayaan bermasalah dapat terjadi karena adanya faktor penyebab dari sisi internal maupun sisi eksternal. Menurut (Anisa \& Tripuspitorini, 2019) faktor internal merupakan faktor yang berasal dari kegiatan operasional di dalam bank itu sendiri yang dituangkan dalam kinerja keuangan. Kinerja keuangan dapat dilihat melalui rasio keuangannya sebagai indikator kesehatan bank seperti NPF, CAR, FDR, dan ROE. Faktor eksternal bank merupakan faktor yang berasal bukan dari kegiatan operasional bank, tetapi bisa berasal dari faktor makroekonomi. Menurut (Tripuspitorini \& Setiawan, 2020) makroekonomi ditujukan untuk mempelajari bagaimana perekonomian bekerja sebagai suatu keseluruhan, dengan demikian hubungan-hubungan sebab akibat yang ingin dipelajari oleh ilmu ekonomi makro pada dasarnya adalah hubungan antar variabel ekonomi agregatif seperti inflasi, BI Rate $e_{3}$ GDP, dan IHSG. 
Berdasarkan pemaparan data mengenai pengaruh faktor internal dan faktor eksternal yang mempengaruhi Non Performing Financing atau NPF dan kasus yang bersumber dari beberapa portal berita mendorong penulis ingin meneliti lebih lanjut mengenai pengaruh faktor internal(FDR dan CAR) dan faktor eksternal (Inflasi, GDP, BI Rate) pada Bank Umum Syariah dengan judul "ANALISIS PENGARUH FAKTOR INTERNAL dan FAKTOR EKSTERNAL TERHADAP NON PERFORMING FINANCING PADA BANK UMUM SYARIAH".

\section{Tinjauan Pustaka}

\subsection{Non Performing Financing (NPF)}

Menurut (Siamat, 2005) NPF adalah pinjaman yang mengalami kesulitan pelunasan akibat adanya faktor-faktor internal yaitu adanya kesengajaan dan faktor eksternal yaitu suatu kejadian diluar kemampuan kendali kreditur.

Menurut Apriyanthi et al. (2020) dalam kegiatan operasionalnya sehari-hari Bank Syariah dihadapkan pada berbagai macam risiko yang berkaitan dengan fungsinya sebagai intermediaryatau perantara keuangan. Salah satu risiko yang harus dihadapi adalah default nasabah atau kelalaian nasabah dalam memenuhi perjanjian dengan Bank Syariah. Default nisbah ini akan menyebabkan terjadinya pembiayaan bermasalah atau NPF. Bank syariah dalam menghadapi kemungkinan terjadinya kegagalan dalam pembiayaan, perlu melakukan pembinaan dan regular monitoring, yaitu dengan memonitoring secara aktif dan secara pasif. Agar terhindar dari NPF bank perlu berhatihati dalam menilai calon nasabah. Bank perlu menelaah permohonan pembiayaan yang diajukan agar bank memperoleh keyakinan bahwa usaha yang dibiayai layak untuk dijalankan.

\subsection{Capital Adequacy Ratio (CAR)}

Capital Adequacy Ratio (CAR) iadalah besarnya rasio minimum perbandingan antara modal risiko dengan aktiva yang memiliki risiko. CAR memperlihatkan seberapa banyak aktiva bank yang mengandung risiko (kredit, penyertaan, surat berharga, tagihan pada bank lain) ikut dibiayai dari modal bank sendiri. Menurut Dendawijaya (2005) CAR merupakan indikator kemampuan bank untuk menutupi penurunan aktivanya sebagai akibat dari kerugian-kerugian bank yang disebabkan oleh aktiva yang mengandung risiko.

\subsection{Financing to Deposit Ratio (FDR)}

Menurut Veithzal, (2007) FDR adalah rasio yang menggambarkan perbandingan antara besarnya jumlah pinjaman atau jumlah pembiayaan yang diberikan kepada nasabah dengan jumlah dana nasabah keseluruhan yang berhasil dihimpun oleh bank syariah. Sehingga dapat ditarik kesimpulan bahwa FDR adalah rasio yang menunjukkan tingkat kemampuan bank syariah dalam mengembalikan dana kepada pihak ketiga melalui keuntungan yang diperoleh dari pembiayaan-pembiayaan yang telah dilakukan bank syariah.

\subsection{Inflasi}

Menurut BI inflasi adalah kondisi meningkatnya harga-harga secara umum dan terjadi terusmenerus. Kenaikan harga ini menyebabkan adanya tekanan pada perekonomian negara terutama bagi ekonomi masyarakat yang menjadi nasabah pembiayaan bank syariah. Terjadinya inflasi juga akan menimbulkan penurunan daya beli masyarakat.

\subsection{Gross Domestic Product (GDP)}

Menurut Fathonah \& Hermawan (2020) GDP adalah nilai barang atau jasa yang diproduksi oleh suatu negara dengan faktor produksi milik warga tersebut dan negara asing. GDP juga digunakan sebagai indikator untuk mempelajari perekonomian sebuah negara dari waktu ke waktu, maupun sebagai indikator untuk membandingkan beberapa kondisi perekonomian. 


\subsection{BI Rate}

Menurut BI suku bunga dapat didefinisikan sebagai suatu kebijakan yang mencerminkan sikap kebijakan moneter yang diberlakukan oleh Bank Indonesia dan diumumkan kepada umum.

\subsection{Kerangka Pemikiran}

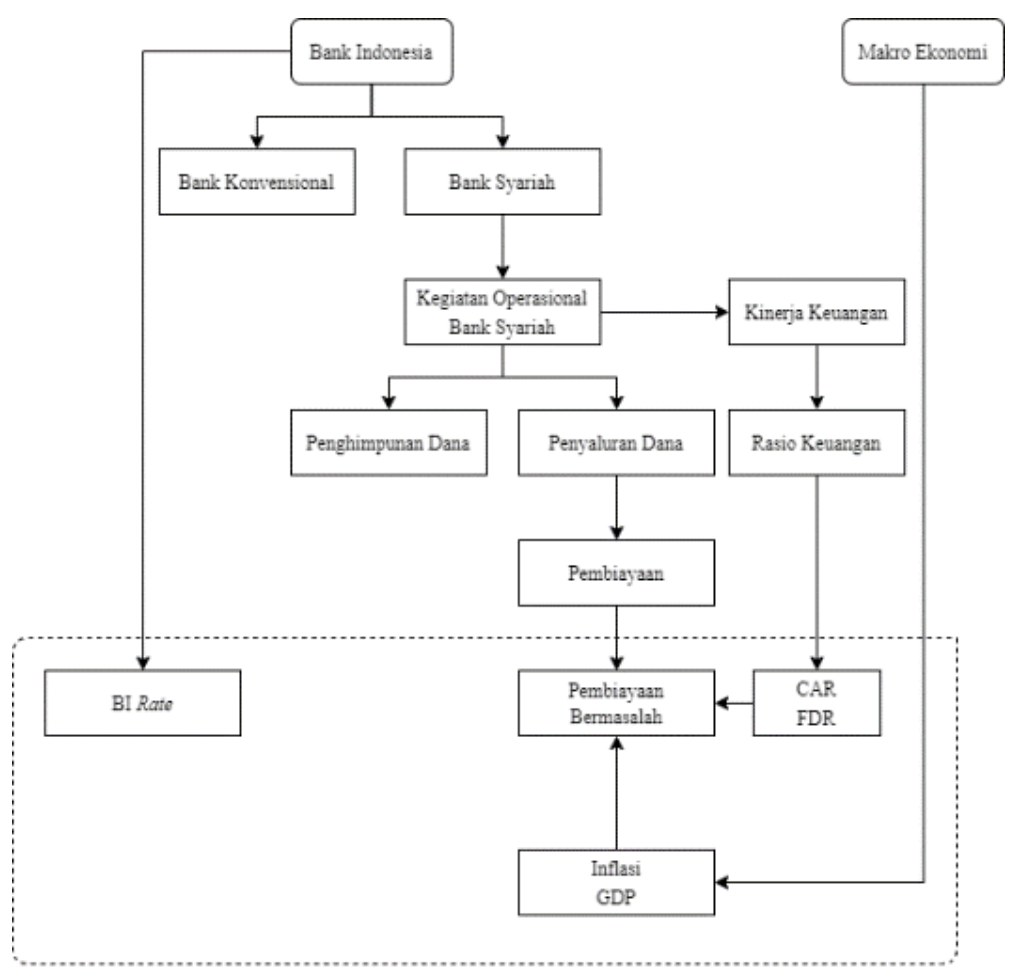

Keterangan: Garis putus-putus menjeleskan ruang lingkup penelitian

Gambar 2. Kerangka Pemikiran

Bank Umum Syariah adalah bank yang melakukan kegiatan usahanya berdasarkan prinsip syariah yang beroperasi di Indonesia. Bank Syariah melakukan kegiatan operasionalnya yang berupa penghimpunan dana dalam bentuk tabungan, giro dan deposito serta penyaluran dana dalam bentuk pembiayaan. Dalam melakukan kegiatan usahanya yaitu pembiayaan, Bank Umum Syariah memiliki risiko berupa pembiayaan bermasalah dimana tingkat pembiayaan bermasalah dicerminkan dalam rasio Non Performing Financing. Beberapa rasio berupa CAR dan FDR yang diambil dari rasio keungan merupakan faktor internal yang dapat mempengaruhi tingkat pembiayaan bermasalah pada Bank Umum Syariah. Indikator makro ekonomi berupa inflasi dan GDP dan juga kebijakan yang diberlakukan oleh Bank Indonesia berupa BI Rate merupakan faktor eksternal yang dapat mempengaruhi tingkat pembiayaan bermasalah pada Bank Umum Syariah.

\subsection{Hipotesis Penelitian}

\section{Pengaruh FDR terhadap NPF}

Rasio FDR menunjukkan besarnya jumlah pembiayaan yang disalurkan oleh bank kepada nasabah, ini artinya semakin tinggi rasio FDR akan mengakibatkan jumlah dana yang disalurkan meningkat. Hal ini juga menunjukkan bahwa ketika rasio jumlah pembiayaan meningkat akan menimbulkan risiko kredit yang tinggi pula. Dengan kata lain, ketika rasio FDR meningkat maka NPF pun akan meningkat. Hasil penelitian yang dilakukan oleh (Nugraini, 2015) mengatakan 
bahwa FDR berpengaruh signifikan postif.

\section{H1: FDR berpengaruh positif terhadap NPF}

\section{Pengaruh CAR terhadap NPF}

CAR merupakan faktor utama dalam menentukan apakah bank mampu untuk menutupi penurunan aktiva-aktivanya sebagai akibat dari adanya kerugian bank. CAR juga erat kaitannya dengan ATMR. Nilai ATMR yang rendah dapat menunjukkan bahwa risiko kredit atau pembiayaan juga rendah. Hasil ini mengindikasikan bahwa permodalan bank syariah yang diwakilkan oleh rasio CAR harus mampu menutupi seluruh risiko usaha yang dihadapi oleh bank, termasuk risiko kerugian yang terjadi akibat terjadinya pembiayaan bermasalah. Apabila CAR meningkat maka dapat diartikan bahwa nilai ATMR rendah. Dengan nilai ATMR yang rendah maka dapat diketahui bahwa risiko pembiayaan juga rendah. Hasil penelitian yang dilakukan oleh (Nugraini, 2015) dan menunjukkan bahwa variabel CAR berpengaruh negatif terhadap NPF.

\section{H2: CAR berpengaruh negatif terhadap NPF}

\section{Pengaruh inflasi terhadap NPF}

Inflasi dianggap dapat membawa dampak buruk bagi pertumbuhan ekonomi dan pertumbuhan kondisi keuangan perusahaan. Naiknya harga barang komoditi dan jasa dalam jumlah yang besar akan menurunkan daya beli dan jumlah konsumsi masyarakat. Dengan menurunnya daya beli dan jumlah konsumsi masyarakat dapat menurunkan minat masyarakat dalam berinvestasi. Hal ini dapat menyebabkan adanya penurunan tingkat pembiayaan yang diberikan kepada masyarakat, sehingga penurunan pembiayaan ini juga akan menurunkan rasio Non Performing Financing (NPF). Hasil penelitian yang dilakukan oleh (Mutamimah \& Chasanah, 2012) menunjukkan bahwa inflasi berpengaruh negatif terhadap NPF

\section{H3: Inflasi berpengaruh negatif terhadap NPF}

\section{Pengaruh GDP terhadap NPF}

GDP merupakan gambaran dari banyaknya jumlah barang dan jasa yang mampu dihasilkan produsen dalam satu periode tertentu. Dengan meningkatnya jumlah produksi barang dan jasa tersebut maka akan meningkatkan pendapatan riil masyarakat yang kemudian akan meningkatkan pertumbuhan ekonomi. Dengan meningkatnya pendapatan riil perusahaan maupun masyarakat akan meningkatkan jumlah konsumsi dan investasi di Bank Syariah. Hal ini juga dapat meningkatkan jumlah pembiayaan yang diberikan kepada masyarakat, dengan meningkatnya jumlah pembiayaan akan meningkatkan rasio Non Performing Financing (NPF). Hasil penelitian yang dilakukan oleh (Popita, 2013) menunjukkan bahwa GDP berpengaruh positif terhadap NPF.

\section{H4: GDP berpengaruh positif terhadap NPF}

\section{Pengaruh BI Rate terhadap NPF}

Bank syariah menggunakan BI Rate sebagai benchmark atau tolak ukur untuk menentukan tingkat bagi hasil agar bank syariah mampu bersaing dengan tingkat suku bunga bank konvensional. Dengan demikian diharapkan ketika bank syariah mampu meningkatkan bagi hasil, masyarakat lebih tertarik untuk meminjam dana dari bank syariah ketimbang bank konvensional. Ketika BI Rate meningkat, maka produk pembiayaan bank akan semakin banyak. Namun kenaikan pembiayaan ini tidak luput dari meningkatnya risiko pembiayaan. Sehingga dapat ditarik kesimpulan bahwa ketika BI Rate meningkat akan meningkatkan besarnya NPF bank syariah. Hasil penelitian yang dilakukan oleh (Hernawati \& Puspasari, 2018) menunjukkan bahwa BI Rate berpengaruh positif signifikan terhadap NPF.

\section{H5: BI Rate berpengaruh positif terhadap NPF}




\section{Metode Penelitian \\ 3.1.Objek Penelitian}

Populasi dari ilaporan ini adalah seluruh Bank Umum Syariah yang terdaftar di Otoritas Jasa Keuangan sampai tahun 2018. Sampel penelitian ini ditentukan sebanyak 10 Bank Umum Syariah yang beroperasi di Indonesia dari periode 2014-2018.

\subsection{Jenis dan Sumber Data}

Jenis idata yang digunakan adalah data sekunder dalam bentuk time series dan cross section yang bersifat kuantitatif yaitu data berupa angka-angka. Data yang digunakan berupa inflasi, BI Rate dan GDP diperoleh dari Laporan Bank Indonesia dan World Bank, sedangkan data CAR, FDR dan NPF diperoleh dari Laporan Keuangan yang dipublikasikan oleh masing-masing bank.

\subsection{Teknik Pengumpulan Data}

Teknik pengumpulan data yang digunakan dalam penelitian ini adalah teknik dokumentasi. Data diambil dan dikumpulkan dari laman resmi masing-masing web. Periodisasi data penelitian yang mencakup data selama periode tahun 2014 sampai dengan tahun 2018.

\subsection{Operasional Variabel Penelitian}

Variabel penelitian iiadalah segala atribut atau sifat atau nilai dari orang, objek atau kegiatan yang mempunyai variasi tertentu yang ditetapkan oleh peneliti untuk dipelajari kemudian diambil kesimpulannya. Berikut merupakan variabel independen dan variabel dependen dalam penelitian ini:

\section{Non Performing Financing (NPF)}

Non Performing Financing iadalah ukuran risiko pembiayaan yang ada di Perbankan syariah. Risiko kredit atau pembiayaan merupakan salah satu utama kondisi suatu bank memburuk. NPF dapat terjadi karena pengaruh dari berbagai kondisi, di antaranya kondisi lingkungan internal dan lingkungan eksternal.

$$
N P F=\frac{\text { Pembiayaan Bermasalah }}{\text { Total Pembiayaan yang disalurkan }} \times 100 \%
$$

\section{Financing to Deposit Ratio (FDR)}

Financing to Deposit Ratio adalah iperbandingan antara jumlah pembiayaan yang diberikan oleh bank dengan dana pihak ketiga yang berhasil dikumpulkan atau dihimpun oleh bank. FDR menggambarkan kemampuan bank syariah dalam mengembalikan dana kepada pihak ketiga atau nasabahnya.

\section{Capital Adequacy Ratio (CAR)}

$$
F D R=\frac{\text { Jumlah Pembiayaan }}{\text { Jumlah DPK }+ \text { Modal Inti }} \times 100 \%
$$

Capital iiAdequacy Ratio merupakan indikator kemampuan bank untuk menutupi penurunan aktivanya sebagai akibat dari kerugian-kerugian bank yang disebabkan oleh aktiva yang mengandung risiko. CAR dapat dihitung dengan rumus:

\section{Inflasi}

$$
C A R=\frac{\text { Modal Sendiri }}{A T M R} \times 100
$$

Inflasi imerupakan kenaikan harga yang bersifat umum dan terjadi secara terus menerus selama satu periode tertentu. Inflasi dapat dihitung dengan menggunakan rumus:

5. Gross Domestic Product (GDP)

$$
\text { Inflasi }=\frac{I H K_{n}+I H K_{n-1}}{I H K_{n-1}} \times 100 \%
$$


GDP merupakan nilai barang dan jasa yang diproduksi di dalam negeri dalam satu periode tertentu. GDP juga merupakan indikator yang penting dalam menilai sebuah pembangunan ekonomi suatu negara. GDP dapat dihitung dengan rumus:

6. BI Rate

$$
G D P=C+I+G+(X-M)
$$

BI Rate merupakan kebijakan yang mencencminkan sikap moneter yang ditetapkan oleh Bank Indonesia dan diimplementasikan pada pengelolaan likuiditas di pasar uang untuk mencapai sasaran kebijakan moneter. Penelitian ini menggunakan data BI Rate yang dipublikasikan oleh Bank Indoneia di halaman resminya www.bi.go.id.

\subsection{Teknik Analisis Data}

Berikut beberapalangkah-langkah analisis yang peneliti lakukan:

\section{Estimasi Data Panel}

Analisis regresi data panel dilakukan agar dapat mengetahui seberapa kuat pengaruh kelima variabel independen terhadap variabel dependen baik secara parsial maupun secara simultan. Adapun persamaan regresi data panel adalah sebagai berikut:

$$
Y=\beta_{0}+\beta_{1} X_{1}+\beta_{2} X_{2}+\beta_{3} X_{3}+\beta_{4} X_{4}+\beta_{4} X_{4}+\varepsilon
$$

Teknik analisis data panel dalam penelitian ini menggunakan 3 (tiga) model data panel yang sering digunakan yaitu Common Effect Model, Fixed Effect Model dan Random Effect Model

a. Uji Chow

Uji ini idilakukan untuk menguji antara model CEM dan FEM. Pengujian tersebut dilakukan dengan program Eviews 11. Uji Chow dilakukan dengan Cara meregresikan data dengan menggunakan model CEM dan FEM

\section{b. Uji Hausman}

Uji ini dilakukan iuntuk menguji antara model FEM dan REM. Pengujian tersebut dilakukan dengan program Eviews 11. Uji Hausman dilakukan dengan Cara meregresikan data dengan menggunakan model REM dan FEM

\section{c. Uji Langrange Multiplier}

Uji ini idilakukan untuk menguji antara model REM dan CEM. Pengujian tersebut dilakukan dengan program Eviews 11. Uji Langrange Multiplier dilakukan dengan Cara meregresikan data dengan menggunakan model REM dan CEM.

\section{Uji Asumsi Klasik}

Berdasarkan pemilihan model regresi data panel, model regresi data yang dipilih adalah random effect model yang termasuk kedalam pendekatan OLS, maka dari itu perlu dilakukan uji asumsi klasik. Uji asumsik klasik yang dilakukan dalam penelitian ini meliputi:

a. Uji Normalitas

Uji iinormalitas dilakukan untuk mengetahui apakah distribusi sebuah data yang didapatkan sesuai atau mendekati hukum normal baku. Pada penelitian ini uji yang dilakukan untuk permasalahan normalitas yaitu uji statistik Jarque-Bera (JB) (Winarno, 2015). Pengambilan keputusan dengan kriteria: Probabilitas $\mathrm{R}^{2}>0,05$ maka data berdistribusi normal, sedangkan apabila probabilitas $\mathrm{R}^{2}<0,05$ maka data tidak terdistribusi normal.

b. Uji Multikolinearitas

Multikolinieritas terjadi apabila jumlah variabel independen yang digunakan lebih dari satu ada korelasi yang cukup tinggi atau signifikan. Uji multikolinieritas dilakukan untuk mengetahui bila 
terjadi korelasi linier antar variabel hingga mendekati sempurna antara satu atau lebih dari variabel bebas. Pengambilan keputusan dengan kriteria jika correlation variabel independen < 0,80 maka tidak terdapat multikolinearitas sedangkan apabila correlation variabel independen $>$ 0,80 maka terdapat multikolinearitas.

\section{c. Uji Heteroskedastisitas}

Menurut Gujarati (2006), uji heteroskedastisitas dilakukan untuk menguji apakah dalam sebuah regresi terjadi ketidaksamaan varian dari residual dari suatu pengamatan ke pengamatan lain. Heteroskedastisitas berarti ada varian pada model yang tidak sama. Pengambilan keputusan dengan kriteria jika Probabilitas $\mathrm{R}^{2}>0,05$ maka data bersifat homoskedastitas sedangkan apabila Probabilitas $\mathrm{R}^{2}<0,05$ maka data bersifat heteroskedastisitas.

\section{d. Uji Autokorelasi}

Uji iiautokorelasi dilakukan untuk menguji apakah dalam suatu model regresi linier ada korelasi antara kesalahan pengguna pada periode $\mathrm{t}$ dengan kesalahan pada periode $\mathrm{t}-1$. Pengambilan keputusan ada atau tidaknya autokorelasi menurut (Santoso, 2012) dapat dilihat sesuai dengan ketentuan berikut:

- Bila nilai D-W $<-2$ maka terdapat autokorelasi positif.

- Bila $-2<\mathrm{D}-\mathrm{W}<2$ maka tidak terdapat autokorelasi.

- Bila D-W > 2 maka terdapat autokorelasi negatif.

\section{Uji Hipotesis}

Dalam penelitian ini dilakukan uji hipotesis yang dinilai berdasarkan uji t, uji $\mathrm{F}$, dan adjusted R-squared.

\section{a. Uji t}

Uji t dilakukan untuk menguji apakah suatu hipotesis diterima atau ditolak, dimana untuk kekuatan pada uji t adalah sebagai berikut:

Hipotesis:

H0 : Tidak ada pengaruh yang berarti dari variabel bebas terhadap variabel terikat.

H1 : Ada pengaruh yang berarti dari variabel bebas terhadap variabel terikat.

Pengambilan keputusan dengan kriteria:

thitung $>$ ttabel, maka $\mathrm{H} 0$ ditolak dan $\mathrm{H} 1$ diterima.

thitung $<$ ttabel, maka $\mathrm{H} 0$ diterima dan $\mathrm{H} 1$ ditolak.

b. Uji F

Uji $\mathrm{F}$ dilakukan untuk mengetahui apakah seluruh variabel independen $\left(\mathrm{X}_{1}, \mathrm{X}_{2}, \ldots, \mathrm{X}_{5}\right)$ memiliki pengaruh secara bersama-sama terhadap variabel dependen (Y). Jika nilai signifikan yang dihasilkan dalam Uji F $P<0,05$, maka dapat disimpulkan bahwa seluruh variabel independen $\left(\mathrm{X}_{1}, \mathrm{X}_{2}, \ldots, \mathrm{X}_{5}\right)$ memiliki pengaruh secara bersama-sama terhadap variabel dependen (Y).

\section{c. Uji Koefisien Determinasi $\left(R^{2}\right)$}

Uji iikoefisien determinansi digunakan untuk mengetahui sampai mana ketepatan atau kecocokan garis regresi yang terbentuk dalam mewakili kelompok data hasil observasi. Untuk mengurangi kelemahan dari koefisien determinasi maka digunakan koefisien determinasi yang telah disesuaikan atau disebut Adjusted $\mathrm{R}^{2}$ (Adj. $\mathrm{R}^{2}$ ) (Suliyanto, 2011) 


\section{HASIL dan PEMBAHASAN}

\subsection{Rancang Uji \\ 4.1.1.Uji Ketepatan Model \\ 4.1.1.1.Uji Chow}

Tabel. 1 Uji Chow

\begin{tabular}{lrrr}
\hline \hline Effects Test & Statistic & d.f. & Prob. \\
\hline \hline Cross-section F & 4.155339 & $(9,35)$ & 0.0010 \\
Cross-section Chi-square & 36.341568 & 9 & 0.0000 \\
\hline \hline
\end{tabular}

UjiChow merupakan uji yang dilakukan untuk menentukan apakah common effect model atau fixed effect model yang paling baik untuk digunakan dalam pemodelan data panel. Berdasarkan hasil pengujian di atas, dapat dilihat hasil bahwa nilai probabilitasnya sebesar 0,0000<0,05 sehingga model yang dipilih adalah fixed effect.

\subsubsection{Uji Hausman}

Tabel. 2 Uji Hausman

\begin{tabular}{lrrr}
\hline \hline Test Summary & $\begin{array}{r}\text { Chi-Sq. } \\
\text { Statistic }\end{array}$ & Chi-Sq. d.f. & Prob. \\
\hline \hline Cross-section random & 0.000000 & 5 & 1.0000
\end{tabular}

Uji Hausman dilakukan untuk menentukan apakah fixed effect model atau random effect model yang paling tepat untuk digunakan dalam pemodelan data panel. Berdasarkan hasil pengujian dengan uji hausman di atas, dapat dilihat hasil bahwa nilai uji hausman hitung adalah sebesar 1.0000 $>0,05$ sehingga model yang dipilih adalah random effect

\subsubsection{Uji Langrange Multiplier}

Tabel.3 Uji Langrange Multiplier

Lagrange Multiplier Tests for Random Effects

Null hypotheses: No effects

Alternative hypotheses: Two-sided (Breusch-Pagan) and one-sided (all others) alternatives

\begin{tabular}{lcll}
\hline \hline & \multicolumn{3}{c}{ Test Hypothesis } \\
& Cross-section & \multicolumn{1}{c}{ Time } & Both \\
\hline \hline Breusch-Pagan & 8.362094 & 2.728728 & $\begin{array}{l}11.09082 \\
(0.0038)\end{array}$ \\
& $(0.0986)$ & $(0.0009)$
\end{tabular}

Berdasarkan ihasil pengujian dengan uji LM di atas, dapat dilihat hasil bahwa nilai uji LM hitung adalah sebesar 0,0038 $<0,05$ artinya nilai uji LM hitung $<$ chi-square tabel maka model yang dipilih adalah random effect. Sehingga dapat disimpulkan model terbaik yang dapat digunakan dalam penelitian ini adalah Random Effect Model.

\subsubsection{Analisis Regresi Data Panel}

Berdasarkan Uji Chow dan Uji Hausman model yang digunakan dalam penelitian ini adalah Random Effect Model. Berikut hasil regresi data panel Random Effect Model: 
Tabel. 4 Regresi Data Panel

\begin{tabular}{crrrr}
\hline \hline Variable & Coefficient & Std. Error & t-Statistic & Prob. \\
\hline \hline C & 3.941160 & 9.383958 & 0.419989 & 0.6765 \\
FDR & 1.679888 & 1.139756 & 1.473902 & 0.1476 \\
CAR & -0.389780 & 0.163287 & -2.387087 & 0.0213 \\
INFLASI & 0.113061 & 0.512795 & 0.220481 & 0.8265 \\
GDP & -1.145409 & 1.306152 & -0.876934 & 0.3853 \\
BIRATE & -1.556192 & 0.719782 & -2.162032 & 0.0361
\end{tabular}

Berdasarkan tabel di atas, maka diperoleh persamaan regresi data panel sebagai berikut: $N P F=3,941+1,679 F D R-0,389$ CAR $+0,113$ INFLASI $-1,145$ GDP $-1,556$ BI RATE $+e$

\subsubsection{Uji Asumsi Klasik}

\subsubsection{Uji Normalitas data}

Tabel. 5 Uji Normalitas

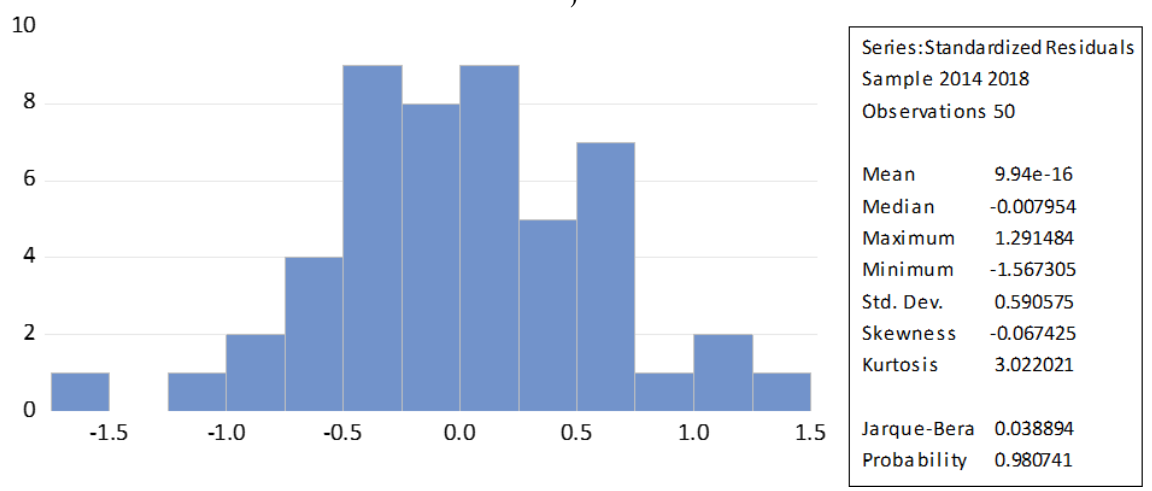

Uji Normalitas dilakukan dengan melakukan Jarque-Bera Test. Berdasarkan hasil pengujian pada gambar diatas menunjukan bahwa data telah berdistribusi secara normal. Hal ini ditunjukan dengan nilai probabilitas Jarque-Bera sebesar 0,9807 yang berada di atas 0,05 yang berarti data residual berdistribusi secara normal.

\subsubsection{Uji Multikolinearitas}

Tabel. 6 Uji Multikolinearitas

\begin{tabular}{ccrrrr} 
& \multicolumn{1}{c}{ FDR } & \multicolumn{1}{c}{ CAR } & INFLASI & \multicolumn{1}{c}{ GDP } & \multicolumn{1}{c}{ BIRATE } \\
\hline \hline FDR & 1.000000 & 0.194408 & 0.273591 & -0.340418 & 0.358921 \\
CAR & 0.194408 & 1.000000 & -0.265145 & 0.314744 & -0.267861 \\
INFLASI & 0.273591 & -0.265145 & 1.000000 & -0.806226 & 0.871907 \\
GDP & -0.340418 & 0.314744 & -0.806226 & 1.000000 & -0.770490 \\
BIRATE & 0.358921 & -0.267861 & 0.871907 & -0.770490 & 1.000000
\end{tabular}

Uji multikolinearitas dilakukan dengan menggunakan Pearson Correlation Test. Berdasarkan hasil pengujian pada gambar di atas tidak ada nilai koefisien korelasi antar variabel yang lebih dari 0,8. Maka dapat disimpulkan bahwa data tidak memiliki masalah multikolinearitas.

\subsubsection{Uji Heteroskedastisitas}

Tabel. 7 Uji Heteroskedastisitas

\begin{tabular}{crrrr}
\hline \hline Variable & Coefficient & Std. Error & t-Statistic & Prob. \\
\hline \hline C & 3.346919 & 6.354802 & 0.526676 & 0.6011 \\
FDR & 0.090704 & 0.672952 & 0.134786 & 0.8934 \\
CAR & 0.180622 & 0.092728 & 1.947873 & 0.0578 \\
INFLASI & 0.279479 & 0.375990 & 0.743316 & 0.4612 \\
GDP & -0.744098 & 0.948879 & -0.784186 & 0.4371 \\
BIRATE & -0.408606 & 0.523589 & -0.780393 & 0.4393
\end{tabular}




\section{Framesa Januari Rahmah, Leni Nur Pratiwi, Iwan Setiawan}

Berdasarkan hasil pengujian yang ditunjukkan pada tabel di atas, diketahui bahwa probabilitas masing-masing variabel berada di atas 0,05 . Hal ini sesuai dengan kriteria pengujian bahwa hasil uji heteroskedastisitas tidak ada nilai probabilitas masing-masing variabel yang kurang dari 0,05. Maka dapat disimpulkan bahwa data tidak memiliki masalah heteroskedastisitas.

\subsubsection{Uji Autokorelasi}

Tabel. 8 Uji Autokorelasi

\begin{tabular}{llll}
\hline \hline & \multicolumn{2}{l}{ Weighted Statistics } & \\
\hline \hline Root MSE & 0.456312 & R-squared & 0.210047 \\
Mean dependent var & 0.713105 & Adjusted R-squared & 0.120279 \\
S.D. dependent var & 0.518619 & S.E. of regression & 0.486430 \\
Sum squared resid & 10.41103 & F-statistic & 2.339900 \\
Durbin-Watson stat & 1.034989 & Prob(F-statistic) & 0.057298
\end{tabular}

Berdasarkan hasil pengujian yang ditunjukkan pada tabel di atas, diketahui nilai DurbinWatson adalah sebesar 1,0349. Hal ini sesuai dengan kriteria pengujian bahwa jika nilai DurbinWatson berada diantara nilai -2 dan 2 maka data terbebas dari autokorelasi. Maka dapat disimpulkan bahwa data tidak memiliki masalah autokorelasi.

\subsubsection{Uji Hipotesis}

\subsubsection{Uji t atau uji signifikansi}

Tabel. 9 Uji t

\begin{tabular}{crrrr}
\hline \hline Variable & Coefficient & Std. Error & t-Statistic & Prob. \\
\hline \hline C & 3.941160 & 9.383958 & 0.419989 & 0.6765 \\
FDR & 1.679888 & 1.139756 & 1.473902 & 0.1476 \\
CAR & -0.389780 & 0.163287 & -2.387087 & 0.0213 \\
INFLASI & 0.113061 & 0.512795 & 0.220481 & 0.8265 \\
GDP & -1.145409 & 1.306152 & -0.876934 & 0.3853 \\
BIRATE & -1.556192 & 0.719782 & -2.162032 & 0.0361 \\
\hline \hline
\end{tabular}

Berikut penjelasan masing-masing hipotesis dari hasil pengujian regresi data panel di atas yaitu sebagai berikut:

Pada tabel 4.9 menunjukkan nilai signifikansi dari FDR yaitu sebesar 0,1476 yang lebih besar dari taraf signifikansi 0,05 dan mempunyai koefisien regresi sebesar 1,679888 sehingga dapat disimpulkan bahwa variabel FDR tidak berpengaruh terhadap NPF. Maka secara parsial $\mathrm{H}_{1}$ ditolak.

Pada tabel 4.9 menunjukkan nilai signifikansi dari CAR yaitu sebesar 0,0213 yang lebih kecil dari taraf signifikansi 0,05 dan mempunyai koefisien regresi sebesar -0,389780, sehingga dapat disimpulkan bahwa variabel CAR berpengaruh negatif signifikan terhadap NPF. Maka secara parsial $\mathrm{H}_{2}$ diterima.

Pada tabel di atas diperoleh nilai signifikansi dari inflasi yaitu sebesar 0,8265 yang berarti lebih besar dari taraf signifikansi 0,05 dan mempunyai koefisien regresi sebesar 0,113061, sehingga dapat disimpulkan bahwa variabel inflasi tidak berpengaruh terhadap NPF. Maka secara parsial $\mathrm{H}_{3}$ ditolak.

Pada tabel di atas diperoleh nilai signifikansi dari GDP yaitu sebesar 0,3853 yang berarti lebih besar dari taraf signifikansi 0,05 dan mempunyai koefisien regresi sebesar 1,145409, sehingga dapat disimpulkan bahwa variabel GDP tidak berpengaruh terhadap NPF. Maka secara parsial $\mathrm{H}_{4}$ ditolak.

Pada tabel di atas diperoleh nilai signifikansi dari BI Rate yaitu sebesar 0,0361 yang berarti lebih kecil dari taraf signifikansi 0,05 dan mempunyai koefisien regresi sebesar -1,556192, sehingga 
dapat disimpulkan bahwa variabel BI Rate berpengaruh negatif signifikan terhadap NPF. Maka secara parsial $\mathrm{H}_{5}$ ditolak.

\subsubsection{Uji $F$ atau uji simultan}

Tabel. 10 Uji F

\begin{tabular}{llll}
\hline \hline & Weighted Statistics & \\
\hline \hline Root MSE & 0.456312 & R-squared & 0.210047 \\
Mean dependent var & 0.713105 & Adjusted R-squared & 0.120279 \\
S.D. dependent var & 0.518619 & S.E. of regression & 0.486430 \\
Sum squared resid & 10.41103 & F-statistic & 2.339900 \\
Durbin-Watson stat & 1.034989 & Prob(F-statistic) & 0.057298
\end{tabular}

Berdasarkan tabel di atas menunjukkan bahwa nilai Prob(F-Statistic) sebesar 0,057298. Karena probabilitasnya lebih besar dari 0,05 maka dapat dikatakan bahwa FDR, CAR, inflasi, GDP, dan BI Rate secara bersama-sama tidak berpengaruh terhadap NPF $\mathbf{H}_{6}$ ditolak.

\subsubsection{Uji Koefisien Determinasi (uji $\mathbf{R}^{2}$ )}

Tabel. 11 Uji R Square

\begin{tabular}{llll}
\hline \hline & \multicolumn{2}{l}{ Weighted Statistics } & \\
\hline \hline Root MSE & 0.456312 & R-squared & 0.210047 \\
Mean dependent var & 0.713105 & Adjusted R-squared & 0.120279 \\
S.D. dependent var & 0.518619 & S.E. of regression & 0.486430 \\
Sum squared resid & 10.41103 & F-statistic & 2.339900 \\
Durbin-Watson stat & 1.034989 & Prob(F-statistic) & 0.057298
\end{tabular}

Berdasarkan tabel di atas dapat diketahui bahwa besarnya adjusted $R^{2}$ yaitu sebesar 0,1202 atau sebesar $12.02 \%$. Dapat disimpulkan bahwa kemungkinan variabel FDR, CAR, inflasi, GDP, dan BI Rate terhadap NPF yang dapat diterangkan oleh model persamaan ini adalah sebesar $12,02 \%$ dan sisanya sebesar $87,98 \%$ dijelaskan oleh variabel yang lain yang tidak terdapat dalam penelitian ini.

\subsection{Pembahasan}

\subsubsection{Financing to Deposit Ratio (FDR) berpengaruh terhadap Non Performing Financing (NPF)}

Pengujian hipotesis pertama dalam penelitian ini untuk variabel pertama yaitu FDR tidak memiliki pengaruh terhadap NPF. Hal ini menunjukkan bahwa semakin besar kenaikan atau penurunan FDR hanya akan memberikan sedikit pengaruh terhadap kenaikan atau penurunan NPF pada Bank Umum Syariah. Hubungan positif antara FDR dengan NPF ini terjadi karena semakin tinggi jumlah dana yang disalurkan bank akan menimbulkan risiko pembiayaan yang bermasalah yang sebanding. Hal ini menunjukkan bahwa jumlah dana di sektor perbankan syariah sudah digunakan secara maksimal dalam menyalurkan pembiayaan. Hasil penelitian ini sejalan dengan hasil penelitian terdahulu yang dilakukan oleh (Nugraini, 2015) dan (Popita, 2013) menyatakan bahwa FDR berpengaruh positif terhadap NPF.

\subsubsection{Capital Adequacy Ratio (CAR) berpengaruh terhadap Non Performing Financing (NPF)}

Pengujian hipotesis kedua dalam penelitian ini untuk variabel kedua yaitu CAR memiliki pengaruh negatif signifikan terhadap NPF. Hal ini menunjukan bahwa semakin kenaikan atau penurunan CAR akan memberikan pengaruh yang signifikan terhadap kenaikan atau penurunan NPF Bank Umum Syariah. Nilai ATMR yang rendah dapat menunjukkan bahwa resiko pembiayaan juga rendah. Hal ini mengindikasikan bahwa permodalan bank syariah yang ditunjukkan oleh rasio CAR harus mampu menutupi seluruh risiko usaha yang dihadapi oleh 
bank, termasuk risiko kerugian yang disebabkan oleh adanya pembiayaan bermasalah. Dengan demikian CAR merupakan faktor penting dalam mitigasi risiko yang dilakukan oleh bank syariah terkait kemungkinan terjadinya pembiayaan bermasalah. Hasil penelitian ini sejalan dengan penelitian yang dilakukan oleh (Nugraini, 2015) dan (Dinnul, 2016) yang menyatakan bahwa variabel CAR berpengaruh negatif terhadap NPF.

\subsubsection{Inflasi berpengaruh terhadap Non Performing Financing (NPF)}

Pengujian hipotesis ketiga dalam penelitian ini untuk variabel ketiga yaitu inflasi tidak memiliki pengaruh terhadap NPF. Hal ini menunjukkan bahwa semakin besar kenaikan atau penurunan inflasi hanya akan memberikan sedikit pengaruh terhadap kenaikan atau penurunan NPF pada Bank Umum Syariah.

Inflasi yang terjadi di tahun penelitian ini mengalami perubahan yang cukup berfluktuatif dan cenderung mengalami penurunan. Meskipun terjadi kenaikan inflasi pada beberapa tahun penelitian, kenaikan ini tidak separah pada saat kenaikan inflasi yang menyebabkan krisis moneter pada tahun 1997/1998 yang mencapai hyper inflation atau pada saat tahun 2008 terjadi krisis ekonomi global dimana tingkat inflasi di Indonesia mencapai $11,06 \%$. Kenaikan atau penurunan tingkat inflasi pada tahun penelitian ini masih terjaga dibawah $10 \%$ atau dikenal sebagai moderate inflation (inflasi satu digit). Sehingga dapat disimpulkan bahwa kenaikan atau penurunan inflasi pada tahun penelitian ini tidak memberikan dampak berarti bagi kenaikan atau penurunan tingkat NPF. Hasil penelitian ini sejalan dengan penelitian yang dilakukan oleh (Manafe, 2017) yang menyatakan bahwa inflasi berpengaruh positif terhadap NPF.

\subsubsection{Gross Domestic Product (GDP) berpengaruh terhadap Non Performing Financing (NPF)}

Pengujian hipotesis keempat dalam penelitian ini untuk variabel keempat yaitu GDP tidak memiliki pengaruh terhadap NPF. Hal ini menunjukkan bahwa semakin besar kenaikan atau penurunan GDP hanya akan memberikan sedikit pengaruh terhadap kenaikan atau penurunan NPF pada Bank Umum Syariah.

Saat perekonomian sektor makro meningkat maka akan meningkatkan aktivitas ekonomi. Dengan meningkatnya aktivitas ekonomi, maka akan berdampak pada peningkatan pendapatan masyarakat dan pada akhirnya akan meningkatkan kapasitas debitur dalam mengembalikan pinjamannya. Ketika kemampuan masyarakat dalam mengembalikan pinjamannya meningkat dan masyarakat membayar pinjamannya tepat waktu maka kemungkinan terjadinya pembiayaan akan berkurang. Sehingga dapat dikatakan bahwa ketika GDP meningkat akan menurunkan tingkat pembiayaan bermasalah. Hasil penelitian ini sejalan dengan penelitian yang dilakukan oleh (Dinnul, 2016)dan (Padmantyo, 2011) yang menyatakan bahwa GDP berpengaruh negatif terhadap NPF.

\subsection{5. $\quad$ BI Rate berpengaruh terhadap Non Performing Financing (NPF)}

Pengujian hipotesis kelima dalam penelitian ini untuk variabel kelima yaitu BI Rate berpengaruh negatif signifikan terhadap NPF. Hal ini menunjukkan bahwa semakin besar kenaikan atau penurunan BI Rate akan memberikan pengaruh yang signifikan terhadap kenaikan atau penurunan NPF pada Bank Umum Syariah.

Hal ini disebabkan karena banyak institusi keuangan syariah melalui pembiayaan menetapkan keuntungan atau menaikkan harga berdasarkan suku bunga yang berlaku saat itu. Semakin tinggi Bank Indonesia dalam menetapkan BI Rate maka pembiayaan diyakini akan menurun karena bank syariah juga menggunakan BI Rate sebagai dasar dalam menentukan margin dan bagi hasil dalam pembiayaan. Tingginya margin dan bagi hasil pembiayaan akan mengurangi atau menurunkan minat masyarakat dalam mengajukan pembiayaan. Dengan menurunnya pembiayaan maka risiko terjadinya pembiayaan bermasalah pun ikut menurun. Hasil 
penelitian ini sejalan dengan penelitian yang dilakukan oleh (Amanah, 2019) yang menyatakan bahwa BI Rate berpengaruh negatif terhadap NPF.

\subsubsection{FDR, CAR, Inflasi, GDP dan BI Rate berpengaruh terhadap Non Performing Financing (NPF).}

Pengujian hipotesis keenam dalam penelitian ini diperoleh nilai Prob(F-Statistic) sebesar 0,057298. Karena probabilitasnya lebih besar dari 0,05 maka dapat dikatakan bahwa FDR, CAR, inflasi, GDP, dan BI Rate secara bersama-sama tidak berpengaruh terhadap NPF. Berdasarkan tabel hasil uji $R$ Square didapatkan nilai adjusted $R^{2}$ sebesar 0,1202 atau sebesar $12.02 \%$. Dapat disimpulkan bahwa kemungkinan variabel FDR, CAR, inflasi, GDP, dan BI Rate terhadap NPF yang dapat diterangkan oleh model persamaan ini adalah sebesar 12,02\% dan sisanya sebesar $87,98 \%$ dijelaskan oleh variabel yang lain yang tidak terdapat dalam penelitian ini. Hasil penelitian ini berbeda dengan penelitian yang dilakukan oleh (Dinnul, 2016) yang menyimpulkan bahwa Variabel Inflasi, GDP, CAR, dan FDR secara simultan bersama-sama berpengaruh terhadap NPF dan penelitian yang dilakukan oleh (Amanah, 2019) yang menyimpulkan bahwa PDB, inflasi, BI Rate, dan nilai tukar rupiah secara simultan berpengaruh positif dan signifikan terhadap NPF.

\section{Penutup}

Berdasarkan hasil penelitian mengenai pengaruh faktor internal dan faktor eksternal terhadap Non Performing Financing pada bank umum syariah di Indonesia tahun 2014-2018 dapat disimpulkan sebagai berikut:

a) Secara parsial variabel CAR dan BI Rate berpengaruh negatif terhadap NPF, yang berarti apabila terjadi kenaikan pada variabel CAR atau BI Rate akan mengakibatkan penurunan pada variabel NPF dan sebaliknya. Sedangkan variabel FDR, inflasi dan GDP tidak berpengaruh terhadap NPF, yang berarti apabila terjadi kenaikan atau penurunan pada variabel FDR, inflasi dan GDP tidak akan memberikan perubahan pada variabel NPF.

b) Secara simultan variabel CAR, FDR, inflasi, GDP dan BI Rate tidak berpengaruh terhadap NPF, yang berarti bahwa variabel NPF dipengaruhi oleh faktor lain di luar variabel CAR dan BI Rate.

Dengan menggunakan prinsip syariah pada pengelolaan bank syariah di Indonesia menunjukkan peningkatan yang pesar pada perkembangan pengelolaan Non Performing Financing, pada rentang waktu penelitian dilihat perbedaan hasil penelitian jika dibandingan dengan penelitian terdahulu. Bank syariah lebih dapat tahan terhadap kondisi ekonomi makro yang berfluktuasi khususnya inflasi dan GDP dibandingkan dengan bank konvensional.

Keputusan bank untuk menyalurkan dana pihak ketiga dalam bentuk pembiayaan merupakan keputusan yang banyak mengandung risiko kerugian terkait dengan pembiayaan. bank selaku lembaga intermediasi yang memperoleh kepercayaan dari para nasabahnya perlu menimbang banyak aspek baik dari sisi teknis dan non teknis baik yang bersifat mikro maupun makro dengan harapan pembiayaan yang disalurkan dapat diperoleh kembali oleh bank sesuai waktunya.

Berdasarkan hasil penelitian serta kesimpulan yang diperoleh, terdapat beberapa implikasi manajerial yang diharapkan dari penelitian ini bagi Bank Umum Syariah dan pihak-pihak terkait dengan pengelolaan sektor perbankan syariah di Indonesia adalah sebagai berikut:

a) Semakin besar aktivitas suatu bisnis maka semakin besar pula risiko yang akan dihadapi seiring dengan perkembangan usahanya. Risiko tersebut tidak mungkin dihapuskan atau dihilangkan namun yang dapat dilakukan adalah bagaimana perbankan syariah mampu mengelola risiko tersebut dan mengubahnya menjadi umpan balik yang positif. 


\section{Framesa Januari Rahmah, Leni Nur Pratiwi, Iwan Setiawan}

b) Perbankan Syariah perlu melakukan pengawasan terhadap tingkat Capital Adequacy Ratio (CAR) karena berdasarkan hasil uji estimasi nilai CAR berpengaruh dalam menurunkan NPF, akan tetapi tingkat CAR tetap harus dijaga agar tetap berada pada nilai batas yang ditetapkan oleh Bank Indonesia. Selain itu, Bank Umum Syariah perlu melakukan pengawasan terhadap tingkat biaya overhead sehingga dalam kegiatan operasional biaya overbead yang digunakan dapat lebih efisien.

c) Bank Umum Syariah harus lebih peka terhadap kondisi makroekonomi terutama tingkat BI Rate sehingga dapat menentukan kebijakan pembiayaan secara tepat agar dapat mengendalikan tingkat NPF pada taraf yang wajar.

d) Peneliti selanjutnya dapat menggunakan variabel internal lain seperti KPMM dan BOPO dan variabel eksternal lain seperti kurs. Selain itu dapat juga dengan memperluas cakupan objek penelitian serta menganalisis dari sisi internal debitur agar didapatkan hasil yang beragam.

\section{Daftar Pustaka}

Amanah, T. (2019). Pengaruh Produk Domestik Bruto, Inflasi, BI Rate, dan Nilai Tukar Rupiah Terhadap Pembiayaan Bermasalah Dalam Perspektif Ekonomi Islam. Raden Intan Repository, 53(9), 1689-1699.

Anisa, L. S., \& Tripuspitorini, F. A. (2019). Analisis Pengaruh Dana Pihak Ketiga, Non Performing Finance Murabahah, dan Inflasi Terhadap Pembiayaan Murabahah Pada Bank Umum Syariah di Indonesia. Jurnal Maps (Manajemen Perbankan Syariah), 52-64.

Apriyanthi, R., Purbayanti, R., \& Setiawan. (2020). Faktor - Faktor Yang Mempengaruhi Pembiayaan Sektor Konstruksi Pada Perbankan Syariah di Indonesia. Probank: Jurnal Ekonomi dan Perbankan, 5(1).

Dendawijaya, L. (2005). Manajamen Lembaga Keuangan. Jurnal Akuntansi.

Dinnul, A. (2016). Inflasi, Gross Domesctic Product (GDP), Capital Adequacy Ratio (CAR), dan Finance To Deposit Ratio (FDR) Terhadap Non Performing Financing (NPF) Pada Bank Umum Syariah di Indonesia. I-Economics.

Fathonah, A. S., \& Hermawan, D. (2020). Estimasi Pengaruh Faktor Internal Bank dan Stabilitas Makroekonomi Terhadap Profitabilitas Dengan Mediasi Rasio Pembiayaan Bermasalah di Pt Bank Muamalat Indonesia. Jurnal Maps (Manajemen Perbankan Syariab), 3(2), 93-108.

Frianto, P. (2012). Manajemen Dana dan Kesehatan Bank. in Manajemen Dana dan Kesehatan Bank.

Gujarati, D. N. (2006). Econometria Básica. in Basic Econometrics.

Hernawati, H., \& Puspasari, O. R. (2018). Pengaruh Faktor Makroekonomi Terhadap Pembiayaan Bermasalah. Journal Of Islamic Finance And Accounting.

Hidayah, A. N. (2019). Analisis Pengaruh Faktor Internal dan Eksternal Terhadap Terjadinya Non Performing Financing Pada Pt. Bank Negara Indonesia Syariah Periode 2011-2018.

Manafe, Y. E. (2017). Pengaruh Inflasi Terhadap Non Performing Financing (NPF) Pada Pt. Bank Syariah Mandiri di Indonesia. Eprint Uin Raden Fatab Palembang, 12-21.

Mutamimah, S., \& Chasanah, N. Z. (2012). Analisis Eksternal dan Internal Dalam Menentukan Non Performing Financing Bank Umum Syariah di Indonesia. Jurnal Bisnis dan Ekonomi (Jbe).

Nugraini, Y. (2015). Analisis Pengaruh Faktor Eksternal dan Internal Terhadap Non Performing Financial (NPF) Pada Bank Umum Syariah di Indonesia. Unissula Repository, 1-28.

Padmantyo, S. (2011). Analisis Variabel Yang Mempengaruhi Kredit Macet di Indonesia. Laporan Penelitian Intensif Reguler Kompetitif., 1 Of 21.

Popita, M. S. A. (2013). Non Performing Financing. Determinan Non Performing Financing (NPF) Bank 
Pembiayaan Rakyat Syariah (Bprs) di Indonesia Tabun 2011-2015.

Santoso, S. (2012). Panduan Lengkap Spss Versi 20. in Pt Elex Media Komputindo.

Siamat, D. (2005). Manajemen Lembaga Keuangan. "Kebijakan Moneter dan Perbankan.” Jakarta: Fakultas Ekonomi Universitas Indonesia, Edisi Kesatu.

Suliyanto. (2011). Uji R. in Ekonometrika Terapan.

Tripuspitorini, F. A., \& Setiawan. (2020). Pengaruh Faktor Makroekonomi Terhadap Pertumbuhan Dana Pihak Ketiga Pada Bank Umum Syariah di Indonesia. Jumal Riset Akuntansi dan Keuangan,8 (1), 2020, 121-132, 8(1), 121-132.

Veithzal, R. And Others. (2007). Bank And Financial Institute Management. Jakarta: Pt. Raja Grafindo Persada.

Winarno, W. W. (2015). Analisis Ekonometrika dan Statistika Dengan Eviews. Edisi Ketiga. in Upp Stim Ykpn. Yogyakarta. 